\title{
Autoantibodies against citrullinated- lipopolysaccharide binding protein as a novel biomarker in seronegative rheumatoid arthritis
}

Xiaozhen Zhao ( $18310180028 @ 163 . c o m$ )

Peking University People's Hospital https://orcid.org/0000-0002-9733-057X

\section{Yuling Chen}

Tsinghua University School of Life Sciences

\section{Yongjing Cheng}

Peking University First Hospital

\section{Wen Wen}

Beijing Tsinghua Changgung Hospital

Yuhui Li

Peking University People's Hospital

\section{Rulin Jia}

Peking University People's Hospital

Haiteng Deng

Tsinghua University School of Life Sciences

\section{Xiaolin Sun}

Peking University People's Hospital

\section{Zhanguo Li}

Peking University People's Hospital

\section{Research article}

Keywords: rheumatoid arthritis, ACPA, lipopolysaccharide binding protein

Posted Date: May 28th, 2020

DOI: https://doi.org/10.21203/rs.3.rs-31058/v1

License: (c) (i) This work is licensed under a Creative Commons Attribution 4.0 International License. Read Full License 


\section{Autoantibodies against citrullinated-lipopolysaccharide binding protein as a novel biomarker in seronegative rheumatoid arthritis}

Xiaozhen Zhao ${ }^{1,2^{*}}$, Yuling Chen ${ }^{* *}$, Yongjing Cheng ${ }^{5}$, Wen Wen ${ }^{4}$, Yuhui $\mathrm{Li}^{1,2}$, Rulin Jia ${ }^{1,2}$, Haiteng

Deng $^{6 *}$, Xiaolin Sun ${ }^{1,2 *}$, Zhanguo $\mathrm{Li}^{1,2,3^{*}}$

${ }^{1}$ Department of Rheumatology and Immunology, Clinical Immunology Center;Peking University People's Hospital, No.11 Xizhimen South Street, Beijing, 100044, China.

${ }^{2}$ Beijing Key Laboratory for Rheumatism Mechanism and Immune Diagnosis (BZ0135)

${ }^{3}$ Peking-Tsinghua Center for Life Science, Beijing, China.

${ }^{4}$ Beijing Tsinghua Changgung Hospital, School of Clinical Medicine, Tsinghua University

${ }^{5}$ Department of Rheumatology and Immunology, National Center of Gerontology, Beijing

Hospital, China,

${ }^{6}$ MOE Key Laboratory of Bioinformatics, School of Life Sciences, Tsinghua University, Beijing,

China

*Xiaozhen Zhao and Yuling Chen contributed equally to this work.

${ }^{*}$ To whom correspondence should be addressed to:

Dr. Xiaolin Sun and Prof. Zhanguo Li

Department of Rheumatology and Immunology/Clinical Immunology Center, Peking University People's Hospital, 11 Xizhimen South Street, Beijing, 100044, China, Tel: 86-10-88324173, Fax: 86-10-88324372, E-mail: sunxiaolin_sxl@126.com; li99@bjmu.edu.cn;

Dr. Haiteng Deng_

MOE Key Laboratory of Bioinformatics, School of Life Sciences, Tsinghua University, Beijing, China, E-mail: dengh@,biomed.tsinghua.edu.cn 


\begin{abstract}
Background

A specific feature of rheumatoid arthritis is the presence of citrullinated antigen and production of anti-citrullinated protein autoantibodies (ACPA) which can appear years prior to disease onset to trigger immune responses. In this study, the serum citrulline-containing antigens from RA patients were screened and the significance of the antibodies against citrullinated lipopolysaccharide binding protein (anti-cLBP) was studied.
\end{abstract}

\title{
Methods
}

Polypeptides isolated from the serum of patients with RA were identified by the Orbitrap highprecision proteomic technology. And then the citrulline-containing proteins was demonstrated. We synthesized citrullinated LBP peptide based on its richness and possible antigenity. The levels of anti-cLBP were determined in sera of 100 RA, 27 OA, 20 SLE and 50 healthy controls by indirect enzyme-linked immunosorbent assay (ELISA).

\section{Result}

A total of 11 citrulline-containing antigens were identified in proteins from sera of RA patients. By using citrullinated LBP, the antibodies (anti-cLBP) was detected in RA patients, healthy and disease controls. We found that the levels of anti-cLBP were significantly increased in RA patients. The sensitivity and specificity of anti-cLBP antibody were $28.00 \%$ and $95.92 \%$, respectively. In antiCCP-negative and RF-negative RA patients, the prevalences of anti-cLBP were 19.05\% (4/21) and $20.59 \%$ (7/34), respectively. In addition, in RA patients of anti-CCP and RF-double negative, anticLBP was also detectable in $16.67 \%$ (3/18) of the patients. Further analysis of the clinical relevance, we found that anti-cLBP antibody was associated with disease activities in RA. It was noticed that the level of anti-cLBP was closely related with a high incidence of infection in patients with RA.

\section{Conclusion}

Anti-cLBP autoantibody is a novel biomarker in RA, especially in seronegative RA, and associated with disease severity.

\section{Key Words}

rheumatoid arthritis, ACPA, lipopolysaccharide binding protein 


\section{Background}

Rheumatoid arthritis (RA) is a chronic inflammatory joint disease that affects $0.5-1.0 \%$ of the global population and $0.28 \%$ in China [1-3]. It is characterized by systemic inflammation resulting in damaged cartilage and bone, leading to restricted movement and disability. Several factors have been proposed to play a role in the pathogenesis of RA, including infection, genetic and hormonal factors [4-5]. Retrospective analyses have shown that ACPAs begin to accumulate in RA patient sera several years before clinical onset of symptoms [6-7] and the detection of ACPAs is the most specific diagnostic test for RA [8]. Importantly, higher ACPA titers correlate with a more severe disease course. Because of the limited sensitivity (67\%) and specificity (95\%) of ACPAs, RA patients, especially seronegative cases are still facing delayed diagnosis and treatment [9]. We attempted to study potential biomarkers or antigens in serum in RA to facilitate clinical diagnosis.

Serum proteins contains a variety of antigens that may associate with underlying diseases. Citrullinated polypeptides incorporated into serum proteins are potential candidates for diagnostic biomarker screening in RA. At present, proteomics with mass spectroscopy has been applied to the exploration of novel biomarkers in vaious diseases [10]. Van Beers et al. applied it in RA synovial fluid and identified citrullinated apolipoprotein E as a novel autoantigen in RA, which suggested that apolipoprotein E might play an important role in the pathogenesis of RA [11].

In this study, we applied high resolution mass spectrometry with nano-LC combined with Orbitrap Q Exactive mass spectrometer to identify novel citrullinated autoantigens present in the serum of RA patients. The autoantibody against citrulline-containing lipopolysaccharide binding protein (cLBP), one of the identified citrullinated proteins, is significantly increased in RA, especially in seronegative patients and associated with disease severity and infection incidence in RA patients.

\section{Materials and methods}

\section{Study population and serum samples}

Serum samples were obtained from 100 patients with RA (mean age $58.99 \pm 11.58$ years, 73 females and 27 males), 27 patients with osteoarthritis (OA) (mean age 60.23 \pm 9.65 years, 23 females and 4 males), 20 patients with systemic lupus erythematosus (SLE) (mean age 39.42 \pm 12.35 years, 17 
females and 3 males)and 50 healthy volunteers(mean age $56.57 \pm 10.61$ years, 37 females and 13 males). The 28-joint count Disease Activity Score (DAS28) was evaluated (5.11 \pm 1.64$)$. The characteristics of RA patients were listed in Table 1. The serum was collected from inpatient or outpatient clinics of the Department of Rheumatology and Immunology, Peking University People's Hospital. The diagnosis of RA was made according to the 2009 revised ACR/EULAR criteria [12]. OA patients were grouped according to the criteria of the 1995 ACR criteria [13-15]. The 2009 SLICC revision of the ACR classification criteria for SLE [16] was used for the diagnosis of SLE. The healthy volunteers were free from any symptoms of infections. The study was approved by the Ethics Committee of Peking University People's Hospital according to the declaration of Helsinki. All patients had been informed and signed the consent for participation in the study.

Table 1. The clinical characteristics of 100 patients with RA.

\begin{tabular}{ll}
\hline Index & $\mathrm{RA}(\mathrm{n}=100)$ \\
\hline Male/Female & $27 / 73$ \\
Age(year) & $58.99 \pm 11.58$ \\
Duration (year) & $12.34 \pm 8.32$ \\
Swollen joint count(M $\pm \mathrm{SD})$ & $7.40 \pm 8.01$ \\
Tender joints(M $\pm \mathrm{SD})$ & $9.45 \pm 9.53$ \\
ESR(mm/hr) & $51.52 \pm 34.22$ \\
$\mathrm{CRP}(\mathrm{g} / \mathrm{L})$ & $36.90 \pm 44.62$ \\
$\mathrm{DAS} 28$ scores & $5.11 \pm 1.64$ \\
$\mathrm{RF}(\mathrm{IU} / \mathrm{L})$ & $435.79 \pm 642.65$ \\
$\operatorname{IgG}(\mathrm{g} / \mathrm{L})$ & $13.62 \pm 4.21$ \\
$\operatorname{IgA}(\mathrm{g} / \mathrm{L})$ & $3.18 \pm 1.34$ \\
$\operatorname{IgM}(\mathrm{g} / \mathrm{L})$ & $1.26 \pm 0.84$ \\
\hline
\end{tabular}

ESR: erythrocyte sedimentation rate; CRP: C-reaction protein; RF: rheumatoid factor; DAS28: 28joint Disease Activity Score.

\section{Clinical and laboratory information of RA patients}

The clinical and laboratory information of RA patients were collected from the medical record database in Peking University People's Hospital: age, sex, disease duration, number of swollen joints, and number of tender joints, organ involvements, treatments, history of smoke, infection and metabolic disorders. ESR was evaluated by the Westergren method. Serum levels of immunoglobulins (IgG, IgM and IgA), complements (C3, C4), CRP, and rheumatoid factor (RF)- 
IgM were examined by immunonephelometry method. Antikeratin antibodies (AKA),

antiperinuclear factor (APF) and RF-IgG were tested by indirect immunofluorescence assay. Anticitrullinated peptide (anti-CCP) antibodies and glucose phosphate isomerase (GPI) were tested by ELISA. The 28-joint count Disease Activity Score (DAS28) was evaluated as described [17].

\section{Proteomic analysis: LC-MS/MS analysis}

Serum samples were collected and pooled together from 10 RA patients. Low-abundance proteins in serum samples were enriched by ProteoMinerTM enrichment kits (Bio-Rad), separated by SDSPAGE, and stained with Coomassie blue staining solution. Each lane was cut into 10 pieces, followed by reduction with $25 \mathrm{mM}$ of dithiothreitol and alkylation with $55 \mathrm{mM}$ iodoacetamide, then digested with sequencing grade modified trypsin (Promega) at $37^{\circ} \mathrm{C}$ overnight. Peptides were extracted by $50 \%$ acetonitrile and $0.5 \%$ formic acid, and dried by a SpeedVac. The peptides were dissolved in $200 \mathrm{mM}$ tetraethylammonium bromide solution and labeled with TMT reagent. 5\% hydroxylamine was used to quench the reaction after $1 \mathrm{~h}$ of incubation. The labeled peptides were mixed together and desalted by home-made C18 stage tip. Peptides were analyzed by LC-MS/MS with nano-LC combined with LTQ Orbitrap Velos mass spectrometer. The LTQ Orbitrap Velos mass spectrometer was operated in the data-dependent acquisition mode using Xcalibur 2.1.2 software, and there was a single full-scan mass spectrum in the Orbitrap (400-1800 m/z, 6000 resolution) with automatic gain control (AGC) target value of 2e6 followed by 10 MS/MS scans.

The raw data were searched against ipi. HUMAN.v3.82 database using Protein Discoverer 1.2.0. The search parameter were as follows: two missed cleavage of full trypsin digestion was allowed; carbamidomethylation (C) and TMT sixplex (K and N-terminal) were set as the fixed modifications; the oxidation $(\mathrm{M})$ and citrullination $(\mathrm{R})$ were set as the variable modification; precursor ion mass tolerances were set at $20 \mathrm{ppm}$ for all MS acquired in an Orbitrap mass analyzer; and the fragment ion mass tolerance was set at $0.5 \mathrm{Da}$ for all MS2 spectra acquired. Relative protein quantification was performed using Proteome Discoverer software according to manufacturer's instructions on the reporter ion intensities per peptide.

\section{Enzyme-linked immunosorbent assay (ELISA)}

14 citrullinated polypeptides were synthesized by CHINESE PEPTIDE. Serum concentrations of antibodies against the 14 citrulline containing peptides were determined by ELISA. Briefly, 96 well polysorp plates (NUNC, Denmark) were coated with recombinant citrullinated polypeptides 
at a concentration of $10 \mu \mathrm{g} / \mathrm{ml}$ in $0.05 \mathrm{M}$ carbonate buffer at $4^{\circ} \mathrm{C}$ overnight. The wells were then washed with PBS with $0.05 \%$ Tween-20 (PBS-T) three times and blocked with 3\% BSA-PBS for 2 hours at $37^{\circ} \mathrm{C}$. Serum samples were diluted at 1:100 with PBS-T containing $1 \%$ BSA and were added to the 96-well plate. Wells filled by PBS-T containing 1\% BSA without human serum samples were set up to examine non-specific background. After incubation for 30 minutes at $37^{\circ} \mathrm{C}$, all the wells were washed for three times with PBS-T. Then, 100ul of goat anti-human IgG conjugated to peroxidase, diluted at 1:16000 with 1\% BSA in PBS-T, was added to each well and incubated for 20 minutes at $37^{\circ} \mathrm{C}$. After washing with PBS-T for three times, the bound antibodies were detected with o- phenylenediamine (OPD) as substrate. The reaction was stopped by adding 100ul of 2M sulfuric acid to each well. Absorbance density (OD) was determined at $450 \mathrm{~nm}$ by a Bio-Rad plate reader. The values of OD of anti-citrullinated protein antibodies were transformed to arbitary units (AU), calculated as below:

$\mathrm{AU}=\left[\mathrm{OD} \text { peptide }-\mathrm{OD}_{\text {nonspecific background }}\right]_{\text {test serum }} /$

$\left[\mathrm{OD}_{\text {peptide }}-\mathrm{OD}_{\text {nonspecific background }}\right]_{\text {positive control serum }} \times 100$

The AU value was considered positive if it was greater than the mean $+2 \times$ standard deviation of the healthy group.

\section{Data analysis}

Data analyses were performed using SPSS 19.0 for Windows. The distribution of numerical data was evaluated by Shapiro-Wilk test. Numerical data with normal distribution were expressed as the mean \pm standard and differences between two groups were analyzed by independent $t$-test. Numerical data with skewed distribution were expressed as median (P25, P75) and differences between two groups were analyzed by Mann-Whitney test. Ranked data were expressed as percentage and differences between two groups were analyzed by chi-square test. Spearman's rank correlation coefficient was applied to determine the correlations. A difference between groups was considered to be significant if $\mathrm{p}<0.05$.

\section{Results}

\section{Identification of citrulline-containing proteins in serum of rheumatoid arthritis}

Eleven antigens derived from serum of RA patients are identified and summarized in Table 2. 
These proteins contain at least one citrulline and are involved in immune response (complement C3), blood pressure (Angiotensinogen) and lipid transportation (apolipoprotein B-100 precursor). Eight of the above 11 proteins are possible novel antigens in RA which have not been previously reported (Table 2). Apolipoprotein A-I, complement C3 and angiotensinogen have been identified in RA synovial fluids.

Table 2. Citrullinated sites detected in serum proteins from patients with rheumatoid arthritis

\begin{tabular}{lll}
\hline Protein name & Citrulline sites & IPI \\
\hline \multirow{2}{*}{ apolipoprotein B-100 precursor } & NEW-Cit-QVSHAKEKL & IPI00022229.2 \\
& KL-Cit-LEPLKHVAGNLK & \\
Apolipoprotein A-I & NIQ-Cit-ANLFNKLVTELRGLS & \\
Apolipoprotein C-III & DSG-Cit-DYVSQFEGS & IPI00021841.1 \\
Apolipoprotein D & QQA-Cit-GWVTDGFSS & IPI00021857.1 \\
Complement C3 & ENG-Cit-CIQANYSLME & IPI00006662.1 \\
Complement C1q subcomponent subunit C & CNYLHLSVL-Cit-TEL & IPI00783987.2 \\
Complement C1r subcomponent & CLQ-Cit-SYTVAIAGYAL & \\
Lambda-chain & CSLI-Cit-FNAVLT & IPI00022394.2 \\
Lipopolysaccharide-binding protein & PQYQF-Cit-TLDEFT & IPI00296165.7 \\
Angiotensinogen & LLIYDNNK-Cit-PSGIPDR & IPI00827875.1 \\
Serum amyloid A2 isoform A & CALQSELL-Cit-ITLP & IPI00032311.4 \\
\hline
\end{tabular}

\section{Autoantibodies to citrullinated lipopolysaccharide-binding protein peptide were increased in RA}

To validate the significance of the potential autoantigen epitopes derived from serum proteins, we selected citrulline-containing lipopolysaccharide-binding protein (cLBP) with sequence as CALQSELL-Cit-ITLP, among which 5 amino acids (RITLP) are predicted to be a B cell epitope covering the citrulline site identified by mass spectrometry (data from IMMUNE EPITOPE DATABASE AND ANALYSIS RESOURCE, http://www.immuneepitope.org) ·

Serum levels of autoantibodies against the cLBP were determined by indirect ELISA in RA patients, disease and healthy controls. The antibodies against citrulline-containing LBP (anti-cLBP) were significantly elevated in RA than those from healthy controls, SLE and OA patients (Figure 1 and Table 3, $\mathrm{p}<0.05)$. 
Table 3. Prevalence of anti-cLBP antibodies in RA patients and controls.

\begin{tabular}{llllll}
\hline Group & No. of & AU value & \multicolumn{2}{l}{ Positivity of anti-cLBP } & \\
& patients & & No. of patients & Sensitivity & \multicolumn{2}{l}{ Specificity } \\
& & & & $(\%)$ & $(\%)$ \\
\hline RA & 100 & $71.86 \pm 53.10$ & 28 & 28.00 & 95.92 \\
RF (-) RA & 34 & $59.13 \pm 46.29$ & 7 & 20.59 & - \\
Anti-CCP (-) RA & 21 & $49.71 \pm 30.12$ & 4 & 19.05 & - \\
Anti-CCP (-)/RF (-) RA & 18 & $48.45 \pm 30.11$ & 3 & 16.67 & - \\
SLE & 20 & $43.83 \pm 15.94$ & 0 & 0 & - \\
OA & 27 & $50.05 \pm 18.79$ & 2 & 7.41 & - \\
HC & 50 & $43.51 \pm 16.71$ & 2 & 4.00 & - \\
\hline
\end{tabular}

Anti-CCP: anti-cyclic citrullinated peptide; RA: rheumatoid arthritis; OA: osteoarthritis; SLE: systemic lupus erythematosus; HC: healthy controls.

The sensitivity and specificity of anti-cLBP antibodies in the diagnosis of RA were $28.00 \%$ and $95.92 \%$, respectively (Table 3). Surprisingly, the prevalence of anti-cLBP was $20.59 \%$ (7/34) or $19.05 \%(4 / 21)$ in RF negative or anti-CCP negative RA patients respectively. Three out of 18 (16.67\%) patients with high anti-cLBP were found from 18 patients with both anti-CCP and RF negative. These results revealed that anti-cLBP antibody might be a valuable biomarker when there is a need of distinguishing serological RA patients from patients with arthralgia caused by other autoimmune diseases.

\section{Anti-cLBP antibody was associated with disease activity in rheumatoid arthritis}

As shown in Table 4, The anti-cLBP antibody was shown to be marginally associated with DAS28 $(\mathrm{r}=0.194, \mathrm{P}=0.059)$. We also showed that RA patients with higher serum levels of anti-cLBP antibodies showed increased joints pain and swollen incidence $(53.57 \%$ vs $44.44,67.86 \%$ vs 48.61\%; Table 5, at the end of the article) and RA patients with high CRP showed higher levels of anti-cLBP $(78.40 \pm 56.29$ vs $55.86 \pm 40.90, \mathrm{p}=0.049$, Table 6 , at the end of the article), which indicated that anti-cLBP antibodies were positively associated with the inflammation and disease activity of RA. 
Table 4. Correlation of serum anti-cLBP antibody with clinical features of RA patients.

\begin{tabular}{|c|c|c|}
\hline \multirow{2}{*}{ Laboratory features } & \multicolumn{2}{|c|}{ anti-cLBP antibody levels (AU) } \\
\hline & spearman $\mathrm{r}$ & $\mathrm{p}$ \\
\hline Duration (years) & 0.099 & 0.329 \\
\hline Tender joints, number & 0.011 & 0.911 \\
\hline Swollen joints, number & 0.096 & 0.343 \\
\hline LBP concentration(ug/ml) & 0.376 & 0.001 \\
\hline $\mathrm{WBC}(\times 109 / \mathrm{L})$ & 0.177 & 0.080 \\
\hline $\operatorname{ESR}(\mathrm{mm} / \mathrm{h})$ & 0.143 & 0.157 \\
\hline $\mathrm{CRP}(\mathrm{mg} / \mathrm{L})$ & 0.151 & 0.137 \\
\hline RF-IgG (IU/mL) & 0.250 & 0.183 \\
\hline Anti-CCP (U/mL) & 0.244 & 0.020 \\
\hline GPI (mg/L) & 0.172 & 0.242 \\
\hline $\operatorname{IgA}(\mathrm{g} / \mathrm{L})$ & 0.263 & 0.010 \\
\hline $\operatorname{IgG}(\mathrm{g} / \mathrm{L})$ & 0.311 & 0.002 \\
\hline $\operatorname{IgM}(\mathrm{g} / \mathrm{L})$ & 0.197 & 0.055 \\
\hline $\mathrm{C} 3(\mathrm{~g} / \mathrm{L})$ & 0.077 & 0.457 \\
\hline $\mathrm{C} 4(\mathrm{~g} / \mathrm{L})$ & 0.163 & 0.116 \\
\hline ASO (IU/mL) & 0.167 & 0.105 \\
\hline D-dimer $(\mu \mathrm{g} / \mathrm{mL})$ & 0.248 & 0.018 \\
\hline DAS28 & 0.194 & 0.059 \\
\hline IL-6 & 0.091 & 0.634 \\
\hline IL-8 & 0.158 & 0.274 \\
\hline AKA & 0.00 & 1.000 \\
\hline APF & 0.417 & 0.038 \\
\hline TG & 0.092 & 0.365 \\
\hline TCHO & 0.029 & 0.776 \\
\hline LDL & 0.021 & 0.835 \\
\hline HDL & 0.077 & 0.449 \\
\hline ALT & 0.062 & 0.544 \\
\hline AST & 0.190 & 0.059 \\
\hline
\end{tabular}

$\mathrm{P}<0.05$ were considered statistically significant. AKA: antikeratin antibodies; APF: antiperinuclear factor; GPI: glucose-6-phosphate isomerase; ASO: Anti-streptococcus hemolysin O; WBC: white blood cell; TG: triglyceride; TCHO: total cholesterol; LDL: Low Density Lipoprotein; HDL: high density lipoprotein; ALT: glutamic-pyruvic transaminase; AST: aspartate amino transferase.

Further analysis suggested that anti-cLBP antibodies were positively correlated with the levels of 
anti-CCP, IgG and $\operatorname{Ig} \mathrm{A}(\mathrm{p}<0.05$, Table 4 and Figure $2 \mathrm{~B}-\mathrm{D})$. We found that RA patients with higher serum levels of anti-cLBP antibodies showed higher anti-CCP, RF, APF positivity, AKA positivity and HRF-IgG ( $\mathrm{p}<0.05$, Table 5), and patients positive for RF, AKA, APF, anti-CCP or HRF-IgG had higher levels of anti-cLBP antibodies ( $\mathrm{p}<0.05$, Table 6 ), which suggested that anti-cLBP antibodies were positively associated with autoantibody production.

\section{Anti-cLBP antibody was increased in RA patients with infection}

As shown in Table 5, RA patients with higher anti-cLBP antibody levels showed increased infection incidence than patients with normal anti-cLBP levels (10/28 (35.71\%) vs 11/72 (15.28\%), $\mathrm{p}=0.024)$. We also found that RA patients with infection showed higher levels of anti-cLBP antibodies $(98.43 \pm 76.59$ vs $65.19 \pm 43.56, \mathrm{p}=0.011$, Table 6$)$.

To determine whether the association of anti-cLBP antibodies with infection is specific or not, we examined the association between incidence of infection in RA patients and the positivity of other RA associated autoantibodies including anti-CCP, AKA, APF, HRF and RF, and no significant association was found, which showed that anti-cLBP was the only indication of infection (Table 7).

Table 7 Correlation between anti-cLBP antibody and other RA autoantibodies and infection.

\begin{tabular}{lllll}
\hline laboratory features & $\begin{array}{l}\text { Infection(n=21) } \\
\mathrm{N}(\%)\end{array}$ & $\begin{array}{l}\text { Noninfection(n=79) } \\
\mathrm{N}(\%)\end{array}$ & $\chi 2$ value & $\mathrm{p}$ value \\
\hline anti-cLBP & $10 / 21(47.62)$ & $18 / 79(23.8)$ & 5.075 & $\mathbf{0 . 0 2 4}$ \\
anti-CCP & $16 / 21(76.19)$ & $58 / 79(73.42)$ & 0.066 & 0.797 \\
AKA & $12 / 21(57.14)$ & $36 / 79(45.57)$ & 0.890 & 0.345 \\
APF & $13 / 21(61.90)$ & $41 / 79(51.90)$ & 0.669 & 0.414 \\
HRF & $7 / 21(33.33)$ & $24 / 79(30.38)$ & 0.068 & 0.795 \\
RF & $15 / 21(71.43)$ & $51 / 79(64.56)$ & 0.349 & 0.555 \\
\hline
\end{tabular}

$\mathrm{P}<0.05$ were considered to be statistically significant.

\section{Discussion}

Rheumatoid arthritis (RA) is a systemic autoimmune disease characterized by chronic and erosive polyarthritis caused by abnormal growth of synovial tissue, and leads to irreversible joint disability. The finding of ACPAs is a milestone in the history of RA serology [18]. In this study, we applied high resolution mass spectrometry to screen serum proteins incorporated citrulline modifications 
from RA patients. A total of 11 citrulline-containing proteins were identified in the serum of RA patients, including LBP, Apo A-I, et al (Table 2). Eight of the proteins are novelly identified in RA, which have not been previously reported. Apolipoprotein A-I and its citrulline epitope have been reported in RA synovial fluid [11]. The citrulline-containing Complement C3 and angiotensinogen have also been identified in RA patients in previous studies, but the citrulline epitopes identified in this study have not been reported. These proteins were involved in physiological process including immune response, blood pressure and lipid transportation. Two (Apo B-100p and C3) of the identified polypeptides appeared to be citrullinated on more than 1 position (Table 2). Also, it is noteworthy that this set could not contain the whole collection of citrulline containing polypeptides in RA, not only because the MS data only partially covered the polypeptide sequences, but also because of the heterogeneity of citrullination patterns for different RA patients.

Besides the identification of a series of citrulline-containing proteins, we further found that the levels of anti-cLBP were significantly increased in RA patients, especially in seronegative patients. We also confirmed that anti-cLBP antibody was associated with RA disease activity. This result confirmed the feasibility and reliability of protein analysis on novel citrulline-containing antigens in RA.

LBP, a class I acute-phase protein, could mediate innate immune responses after recognizing lipopolysaccharides (LPS) from gram-negative bacterium [19-20]. LBP could form a high-affinity complex with LPS, then LPS was delivered to cell through CD14 or TLR4-MD2 and triggered a cascade of cytokines and pro-inflammatory factors [21]. Previous studies suggested that serum LBP in sepsis significantly elevated almost seven times higher than normal levels [21]. LBP not only exerts a diagnostic value in sepsis, UTI, periodontitis, etc., but also is related to the prognosis and mortality of some types of infections [22-24]. In our study, we found correlation between anti-cLBP antibody and infections. Previous study showed serum LBP level was elevated in RA. The incidence of infection is higher in LBP-positive RA patients than in LBP-negative cases, but there was no statistical difference [21]. LBP can promote infection immunity, contribute to eliminating pathogens, and control the further occurrence of infection. However, anti-cLBP antibody may interfere with LBP normal physiological function. Therefore, RA patients with elevated anti-cLBP antibody are prone to infection. It is necessary to elucidate the pathological roles of anti-cLBP antibody in RA in future investigations. 
However, there were obvious limitations in this study. First, the number of RA patients recruited from our clinical center was limited in this study, and it might restrain the demonstration of clinical correlation of anti-cLBP antibodies due to lack of statistical power. It will be important to recruit more RA patients from multiple clinical centers in our future studies. Another weakness of this study is that we did not reveal the exact pathogenesis of anti-cLBP in RA, especially how it affected immune responses during infection, which should also be revealed in the future investigations.

In conclusion, this study has successfully set up the protein analysis method for RA associated autoantigens by high resolution mass spectrometry, and identified 11 citrulline-containing proteins in the serum of RA patients. Eight of the proteins are novel antigens in RA, which have not been reported before. Two (Apo B-100p and C3) of 11 citrulline-containing proteins appeared to be citrulline on at least 1 position. The identified epitopes of citrulline-containing proteins in RA will be helpful for the development of assays for ACPA profiling. Such profiles may benefit the ACPApositive patients with RA concerning disease responsiveness to some kinds of treatments. The biologic function of many proteins will be affected because of citrullination, and it will be promising to investigate to what extent this contributes to pannus formation and cartilage and bone damage. And we also found that anti-cLBP antibody was elevated in RA, especially in seronegative patients, and correlated with disease activity and infection, which implicated anti-cLBP might be involved in the infection of RA.

\section{Conclusions}

We had set up the protein analysis method for RA associated autoantigens by high resolution mass spectrometry, and identified 11 citrulline-containing proteins in the serum of RA patients. And we revealed that anti-cLBP autoantibody is a novel biomarker in RA, especially in seronegative RA, and associated with disease severity.

\footnotetext{
Abbreviations

ACPA: anti-citrullinated protein autoantibodies; anti-cLBP: antibodies against citrullinated lipopolysaccharide binding protein; RA: rheumatoid arthritis; OA: osteoarthritis; SLE: systemic lupus erythematosus; HC: healthy controls; DAS28: 28-joint count Disease Activity Score; RF: rheumatoid factor; AKA: Antikeratin antibodies; APF: antiperinuclear factor; anti-CCP: anticitrullinated peptide; GPI: glucose phosphate isomerase; OD: absorbance density; AU: arbitary
} 
units; LPS: lipopolysaccharides; ESR: erythrocyte sedimentation rate; CRP: C-reaction protein; ASO: Anti-streptococcus hemolysin O; WBC: white blood cell; TG: triglyceride; TCHO: total cholesterol; LDL: Low Density Lipoprotein; HDL: high density lipoprotein; ALT: glutamic-pyruvic transaminase; AST: aspartate amino transferase; ERY: urine erythrocyte; PRO: urine protein.

Ethics approval and consent to participate. This study was approved by the Ethics Committee of Peking University People's Hospital (Approval number 2018PHB147-01). All participants signed the consent for this study.

Consent for publication. Not applicable.

Availability of data and materials. The datasets for this study can be available from the corresponding authors upon reasonable request.

Competing interests. The authors declare that they have no competing interests.

\section{Funding}

This work was supported by funds from Peking University Clinical Scientist Program (the Fundamental Research Funds for the Central Universities, BMU2019LCKXJ004), National Natural Science Foundation of China (31530020, 81671602, 81801617, 3040290) and Sanming Project of Medicine in Shenzhen (SZSM201612009).

\section{Author Contributions Statement}

$\mathrm{XS}, \mathrm{ZL}$ and $\mathrm{HD}$ initiated the investigation, wrote, reviewed, and edited the manuscript. $\mathrm{XZ}$ and $\mathrm{YC}$ obtained and analyzed the data and wrote, edited, and reviewed the manuscript. WW and YC obtained data and wrote, edited, and reviewed the manuscript. YL and RJ contributed to the design and reviewed and edited the manuscript. All authors gave final approval of the manuscript version to be published.

Acknowledgements Not applicable.

\section{REFERENCES}

[1] Cross, M., Smith, E., Hoy, D., Carmona, L., Wolfe, F., Vos, T., Williams, B., Gabriel, S., Lassere, M., Johns, N., et al. The global burden of rheumatoid arthritis: estimates from the global burden of disease 2010 study. Ann Rheum Dis. 2014;73, 1316-1322.

[2] Smolen JS, Aletaha D, Barton A et al. Rheumatoid arthritis. Nature reviews. Disease primers 2018; 4: 18001.

[3] LI R, SUN J, REN LM et al. Epidemiology of eight common rheumatic diseases in China: a large-scale cross-sectional survey in Beijing. Rheumatology (Oxford, England) 2012; 51(4): 
$721-9$

[4] Van Gaalen FA, van Aken J, Huizinga TW, Schreuder GM, Breedveld FC, Zanelli E, et al. Association between HLA class II genes and autoantibodies to cyclic citrullinated peptides influences the severity of rheumatoid arthritis. Arthritis Rheum. 2004; 50:2113-21.

[5] Padyukov L, Silva C, Stolt P, Alfredsson L, Klareskog L. A gene-environment interaction between smoking and shared epitope genes in HLA-DR provides a high risk of seropositive rheumatoid arthritis. Arthritis Rheum. 2004; 50:3085-92.

[6] van der Helm-van Mil, A.H., Breedveld, F.C., and Huizinga, T.W. Aspects of early arthritis. Definition of disease states in early arthritis: remission versus minimal disease activity. Arthritis Res Ther. 2006; 8: 216.

[7] van Venrooij, W.J., Zendman, A.J., and Pruijn, G.J. Autoantibodies to citrullinated antigens in (early) rheumatoid arthritis. Autoimmun Rev. 2006: 6, 37-41.

[8] Taylor, P., Gartemann, J., Hsieh, J., and Creeden, J. A systematic review of serum biomarkers anti-cyclic citrullinated peptide and rheumatoid factor as tests for rheumatoid arthritis. Autoimmune Dis. 2011; 815038.

[9] Hu F, Jiang X, Guo C, Li Y, Chen S, Zhang W, et al., Scavenger receptor-A is a biomarker and effector of rheumatoid arthritis: A large-scale multicenter study. Nat Commun. 2020; 11(1):1911.

[10] Apweiler R, Aslanidis C, Deufel T, et al. Approaching clinical proteomics: current state and future fields of application in fluid proteomics. Clin Chem Lab Med. 2009; 47(6):724-44.

[11] Van Beers JJ, Schwarte CM, Sammen-Vogelzangs J, et al. The rheumatoid arthritis synovial fluid citrullinome reveals novel citrullinated epitopes in apolipoprotein E, Myeloid nuclear differentiation antigen, and b-actin. Arthritis Rheum.2013; 65(1): 69-80.

[12] ALETAHA D, NEOGI T, SILMAN AJ et al. 2010 Rheumatoid arthritis classification criteria: an American College of Rheumatology/European League Against Rheumatism collaborative initiative. Arthritis Rheum. 2010; 62: 2569-81.

[13] ALTMAN R, ALARCON G, APPELROUTH D et al. The American College of Rheumatology criteria for the classification and reporting of osteoarthritis of the hip. Arthritis Rheum. 1991; 34: 505-14.

[14] ALTMAN R, ALARCON G, APPELROUTH D et al. The American College of Rheumatology 
criteria for the classification and reporting of osteoarthritis of the hand. Arthritis Rheum. 1990; 33: $1601-10$.

[15] ALTMAN R, ASCH E, BLOCH D et al.: Development of criteria for the classification and reporting of osteoarthritis. Classification of osteoarthritis of the knee. Diagnostic and Therapeutic Criteria Committee of the American Rheumatism Association. Arthritis Rheum. 1986; 29: 1039-49.

[16] COSTEdoat-Chalumeau N, FRAnCES C, POUCHOT J, PIETTE JC. The new classification criteria for systemic lupus erythematosus (SLICC). Rev Med Interne. 2014; 35: $487-90$.

[17] SCHOELS M, KNEVEL R, ALETAHA D et al. Evidence for treating rheumatoid arthritis to target: results of a systematic literature search. Ann Rheum Dis. 2010; 69: 638-43.

[18] Baka, Z.; György, B.; Géher, P.; Buzás, E.I.; Falus, A.; Nagy, G. Citrullination under physiological and pathological conditions. Joint Bone Spine. 2012; 79, 431-436.

[19] Aylett $\mathrm{CH}$, Lowe J, Amos LA. New insights into the mechanisms of cytomotive actin and tubulin filaments. International review of cell and molecular biology. 2011; 292:1-71.

[20] Hein S, Scheffold T, Schaper J. Ischemia induces early changes to cytoskeletal and contractile proteins in diseased human myocardium. The Journal of thoracic and cardiovascular surgery. 1995; 110(1):89-98.

[21] W. Wen, Y. Li, Y. Cheng, J. He, R. Jia, C. Li, et al., Lipopolysaccharide-binding protein is a sensitive disease activity biomarker for rheumatoid arthritis. Clinical and Experimental Rheumatology. 2018; 36: 233-240.

[22] SAHEBARI M, GOSHAYESHI L, MIRFEIZI Z et al. Investigation of the association between metabolic syndrome and disease activity in rheumatoid arthritis. Scientific World-Journal. 2011; 11: 1195-205.

[23] BELLUCCI E, TERENZI R, LA PAGLIA GM et al. One year in review 2016: pathogenesis of rheumatoid arthritis. Clin Exp Rheumatol. 2016; 34: 793-801.

[24] Taddonio MA, Dolgachev V, Bosmann M et al. Influence of lipopolysaccharide binding protein on pulmonary inflammation in gram-negative pneumonia. Shock. 2015; 43: 612-19. 
Table 5 Clinical and laboratory characteristics of RA patients with the elevated and normal levels of serum anti-cLBP antibodies.

\begin{tabular}{|c|c|c|c|c|c|c|}
\hline \multirow{3}{*}{ Clinical and laboratory features } & \multicolumn{6}{|c|}{ anti-cLBP antibodies } \\
\hline & \multicolumn{2}{|c|}{ Positive (28) } & \multicolumn{2}{|c|}{ Negative (72) } & \multirow{2}{*}{$t / u / \chi^{2}$} & \multirow{2}{*}{$\mathrm{p}$} \\
\hline & $\mathrm{N}$ & $\%$ & $\mathrm{~N}$ & $\%$ & & \\
\hline female & $21(28)$ & 75.00 & $52(72)$ & 72.22 & 0.079 & 0.779 \\
\hline Tender joints $\geqslant 6$ & $15(28)$ & 53.57 & $32(72)$ & 44.44 & 0.672 & 0.412 \\
\hline Swollen joints $\geqslant 4$ & $19(28)$ & 67.86 & $35(72)$ & 48.61 & 3.006 & 0.083 \\
\hline somke & $6(28)$ & 21.43 & $15(72)$ & 20.83 & 0.004 & 0.948 \\
\hline Interstitial lung disease & $17(27)$ & 62.96 & $37(72)$ & 51.39 & 1.061 & 0.303 \\
\hline Infection & $10(28)$ & 35.71 & $11(72)$ & 15.28 & 5.075 & 0.024 \\
\hline Cardiac involvements & $1(27)$ & 3.70 & $1(72)$ & 1.39 & 0.532 & 0.466 \\
\hline Renal involvements & $0(27)$ & 0 & $2(71)$ & 2.82 & - & 1.000 \\
\hline Skin & $3(27)$ & 11.11 & $8(71)$ & 11.27 & 0.000 & 1.000 \\
\hline Haematological involvements & $11(27)$ & 40.74 & $26(71)$ & 36.62 & 0.141 & 0.707 \\
\hline RF & \multicolumn{2}{|c|}{$542.3 \pm 543.82$} & \multicolumn{2}{|c|}{$335.49 \pm 683.30$} & 1.358 & 0.035 \\
\hline $\operatorname{ESR}(\mathrm{mm} / \mathrm{h})$ & \multicolumn{2}{|c|}{$58.16 \pm 37.17$} & \multicolumn{2}{|c|}{$49.96 \pm 33.55$} & 0.939 & 0.350 \\
\hline $\mathrm{CRP}(\mathrm{mg} / \mathrm{L})$ & \multicolumn{2}{|c|}{$48.79 \pm 46.22$} & \multicolumn{2}{|c|}{$34.26 \pm 44.11$} & 1.253 & 0.213 \\
\hline AKA & $18(26)$ & 69.23 & $26(70)$ & 37.14 & 7.863 & 0.005 \\
\hline APF & $20(26)$ & 76.92 & $34(70)$ & 48.57 & 6.192 & 0.013 \\
\hline anti-CCP & \multicolumn{2}{|c|}{$166.41 \pm 77.50$} & \multicolumn{2}{|c|}{$120.25 \pm 83.17$} & 2.038 & 0.035 \\
\hline HRF-IgG & $12(24)$ & 50.00 & $16(70)$ & 22.86 & 4.422 & 0.035 \\
\hline GPI & $12(22)$ & 60.00 & $30(67)$ & 44.77 & 0.634 & 0.426 \\
\hline ERY & $0(27)$ & 0 & $7(68)$ & 10.29 & 1.682 & 0.195 \\
\hline PRO & $0(27)$ & 0 & $2(68)$ & 2.94 & - & 1.000 \\
\hline $\operatorname{IgG}$ & \multicolumn{2}{|c|}{$14.62 \pm 4.62$} & \multicolumn{2}{|c|}{$13.29 \pm 4.11$} & 1.126 & 0.263 \\
\hline
\end{tabular}




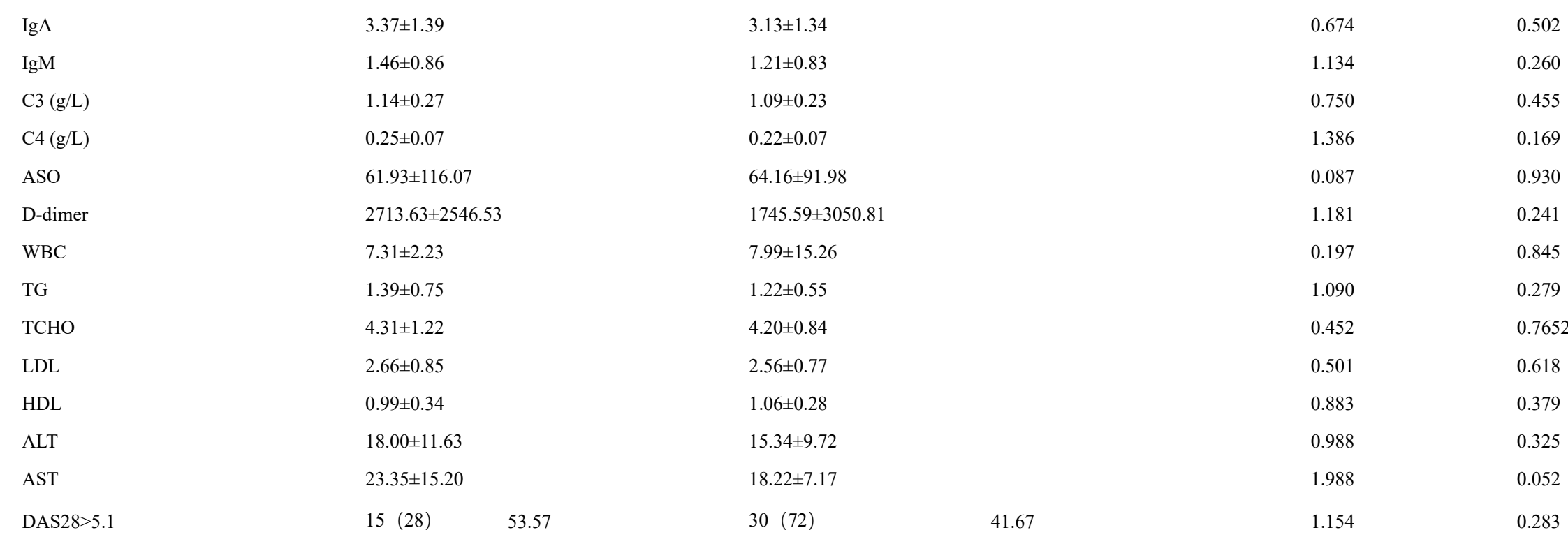

For normally distributed data, results were expressed as mean $\pm \mathrm{SD}$; differences between groups were analyzed with the $\mathrm{t}$ test. Data not distributed normally expressed as median (range), differences were analyzed with the Mann-Whitney U-test. Classified data were presented as n (\%) and analyzed by chi-square $\left(\chi^{2}\right)$ test. $\mathrm{P}<0.05$ were considered statistically significant. ERY: urine erythrocyte; PRO: urine protein. 
Table 6 The levels of serum anti-cLBP antibodies in the presence or absence of clinical or laboratory characteristics of RA patients.

\begin{tabular}{|c|c|c|c|c|}
\hline \multirow{2}{*}{ Clinical and laboratory features } & \multicolumn{4}{|c|}{ anti-cLBP levels (AU) } \\
\hline & Presence & Absence & $t / u$ & $\mathrm{p}$ \\
\hline female & $72.24 \pm 52.56(\mathrm{n}=73)$ & $60.01 \pm 41.58(\mathrm{n}=27)$ & 1.363 & 0.176 \\
\hline Tender joints $\geqslant 6$ & $72.72 \pm 59.08(\mathrm{n}=47)$ & $70.99 \pm 46.95(\mathrm{n}=53)$ & 0.162 & 0.872 \\
\hline Swollen joints $\geqslant 4$ & $77.94 \pm 57.29(\mathrm{n}=54)$ & $64.12 \pm 46.73(\mathrm{n}=46)$ & 1.298 & 0.198 \\
\hline somke & $63.28 \pm 49.218(\mathrm{n}=21)$ & $74.14 \pm 54.15(\mathrm{n}=79)$ & 0.832 & 0.408 \\
\hline Interstitial lung disease & $76.93 \pm 57.57(\mathrm{n}=54)$ & $64.99 \pm 47.37(\mathrm{n}=45)$ & 1.112 & 0.269 \\
\hline Infection & $98.53 \pm 76.59(\mathrm{n}=21)$ & $65.19 \pm 43.56(\mathrm{n}=79)$ & 2.583 & 0.011 \\
\hline Cardiac involvements & $80.57 \pm 54.09(\mathrm{n}=2)$ & $71.32 \pm 53.50(\mathrm{n}=97)$ & 0.242 & 0.809 \\
\hline Renal involvements & $24.24 \pm 17.99(\mathrm{n}=2)$ & $73.06 \pm 53.30(\mathrm{n}=96)$ & 1.288 & 0.201 \\
\hline Skin involvements & $82.63 \pm 73.93(\mathrm{n}=11)$ & $70.73 \pm 50.44(\mathrm{n}=87)$ & 0.697 & 0.488 \\
\hline Haematological involvements & $78.39 \pm 63.73(\mathrm{n}=37)$ & $68.22 \pm 45.88(\mathrm{n}=61)$ & 0.916 & 0.362 \\
\hline $\mathrm{RF}>20(\mathrm{IU} / \mathrm{ml})$ & $78.42 \pm 55.48(\mathrm{n}=66)$ & $59.13 \pm 46.29(\mathrm{n}=34)$ & 2.036 & 0.042 \\
\hline $\mathrm{ESR}>20(\mathrm{~mm} / \mathrm{h})$ & $72.38 \pm 51.96(\mathrm{n}=77)$ & $70.12 \pm 57.94(\mathrm{n}=23)$ & 0.178 & 0.859 \\
\hline $\mathrm{CRP}>8(\mathrm{mg} / \mathrm{L})$ & $78.40 \pm 56.29(\mathrm{n}=71)$ & $55.86 \pm 40.90(\mathrm{n}=29)$ & 1.989 & 0.049 \\
\hline AKA & $86.68 \pm 63.66(\mathrm{n}=48)$ & $55.98 \pm 36.09(\mathrm{n}=48)$ & 2.906 & 0.005 \\
\hline APF & $83.20 \pm 61.61(\mathrm{n}=54)$ & $56.06 \pm 36.83(\mathrm{n}=42)$ & 2.523 & 0.013 \\
\hline anti-CCP & $76.73 \pm 56.90(\mathrm{n}=76)$ & $49.71 \pm 30.12(\mathrm{n}=21)$ & 2.091 & 0.039 \\
\hline HRF-IgG & $82.23 \pm 60.53(\mathrm{n}=31)$ & $62.15 \pm 45.24(\mathrm{n}=63)$ & 2.090 & 0.042 \\
\hline GPI & $66.68 \pm 42.68(\mathrm{n}=46)$ & $67.43 \pm 54.70(\mathrm{n}=43)$ & 0.072 & 0.943 \\
\hline ERY & $36.96 \pm 18.53(\mathrm{n}=7)$ & $74.80 \pm 55.27(\mathrm{n}=88)$ & 1.796 & 0.076 \\
\hline PRO & $37.83 \pm 37.21(\mathrm{n}=2)$ & $72.75 \pm 54.50(\mathrm{n}=93)$ & 0.899 & 0.371 \\
\hline $\mathrm{IgG} \geq 16(\mathrm{~g} / \mathrm{L})$ & $84.41 \pm 53.42(\mathrm{n}=20)$ & $69.17 \pm 54.24(\mathrm{n}=75)$ & 1.120 & 0.266 \\
\hline $\operatorname{IgA} \geq 4.5(\mathrm{~g} / \mathrm{L})$ & $83.22 \pm 61.28(\mathrm{n}=16)$ & $70.18 \pm 52.74(\mathrm{n}=79)$ & 0.877 & 0.383 \\
\hline
\end{tabular}




\begin{tabular}{|c|c|c|c|c|}
\hline $\operatorname{IgM} \geq 3.04(\mathrm{~g} / \mathrm{L})$ & $82.01 \pm 68.70(\mathrm{n}=7)$ & $71.61 \pm 53.24(\mathrm{n}=88)$ & 0.487 & 0.627 \\
\hline $\mathrm{C} 3<0.78(\mathrm{~g} / \mathrm{L})$ & $63.18 \pm 71.71(\mathrm{n}=9)$ & $73.34 \pm 52.42(\mathrm{n}=86)$ & 0.533 & 0.595 \\
\hline $\mathrm{C} 4<0.16(\mathrm{~g} / \mathrm{L})$ & $64.69 \pm 52.36(\mathrm{n}=16)$ & $73.94 \pm 54.69(\mathrm{n}=79)$ & 0.621 & 0.536 \\
\hline $\mathrm{ASO} \geq 116(\mathrm{IU} / \mathrm{mL})$ & $91.22 \pm 63.73(\mathrm{n}=7)$ & $71.08 \pm 52.70(\mathrm{n}=91)$ & 0.960 & 0.339 \\
\hline $\mathrm{D}$-dimer $\geqslant 243(\mathrm{ng} / \mathrm{mL})$ & $77.73 \pm 58.13(\mathrm{n}=75)$ & $50.85 \pm 26.85(\mathrm{n}=15)$ & 1.748 & 0.084 \\
\hline $\mathrm{WBC} \leq 3.5\left(\times 10^{\wedge} 9 / \mathrm{L}\right)$ & $64.42 \pm 17.11(\mathrm{n}=2)$ & $71.65 \pm 53.76(\mathrm{n}=97)$ & 0.189 & 0.850 \\
\hline $\mathrm{TG} \geq 1.7(\mathrm{mmol} / \mathrm{L})$ & $80.72 \pm 59.36(\mathrm{n}=16)$ & $69.73 \pm 52.20(\mathrm{n}=83)$ & 0.335 & 0.754 \\
\hline $\mathrm{TCHO} \geq 6.20(\mathrm{mmol} / \mathrm{L})$ & $116.43 \pm 100.71(\mathrm{n}=3)$ & $70.10 \pm 51.44(\mathrm{n}=96$ & 1.493 & 0.139 \\
\hline $\mathrm{LDL} \geq 4.1(\mathrm{mmol} / \mathrm{L})$ & $81.01 \pm 48.58(\mathrm{n}=3)$ & $71.21 \pm 53.60(\mathrm{n}=96)$ & 0.312 & 0.755 \\
\hline $\mathrm{HDL} \leq 1.03(\mathrm{mmol} / \mathrm{L})$ & $72.46 \pm 50.79(\mathrm{n}=50)$ & $70.53 \pm 56.16(\mathrm{n}=49)$ & 0.179 & 0.858 \\
\hline $\mathrm{ALT} \geq 40(\mathrm{U} / \mathrm{L})$ & $105.05 \pm 76.35(\mathrm{n}=5)$ & $69.72 \pm 51.71(\mathrm{n}=94)$ & 1.454 & 0.149 \\
\hline $\mathrm{AST} \geq 35(\mathrm{U} / \mathrm{L})$ & $67.41 \pm 34.74(\mathrm{n}=5)$ & $71.72 \pm 54.18(\mathrm{n}=94)$ & 0.178 & 0.861 \\
\hline DAS28 $>5.1$ & $73.60 \pm 54.91(\mathrm{n}=51)$ & $70.05 \pm 51.65(\mathrm{n}=49)$ & 0.333 & 0.740 \\
\hline
\end{tabular}

For normally distributed data, results were expressed as mean \pm SD. $\mathrm{P}<0.05$ were considered to be statistically significant. 
Figure Legend

Fig 1: Comparison of serum levels of anti-cLBP antibodies between RA, OA, SLE patients and HC.

ns, $\mathrm{P}>0.05 ; *, \mathrm{P}<0.05 ; * *, \mathrm{P}<0.01 ; * * *, \mathrm{P}<0.001$.

Fig 2: Correlation between anti-cLBP antibody and clinical parameters.

A-D: Anti-cLBP antibodies positively correlated with LBP concentration, anti-CCP, IgG and IgA.

$\mathrm{p}<0.05$ were considered statistically significant. $\mathrm{r}$ : correlation coefficient. 
Figures

\section{Figure 1}

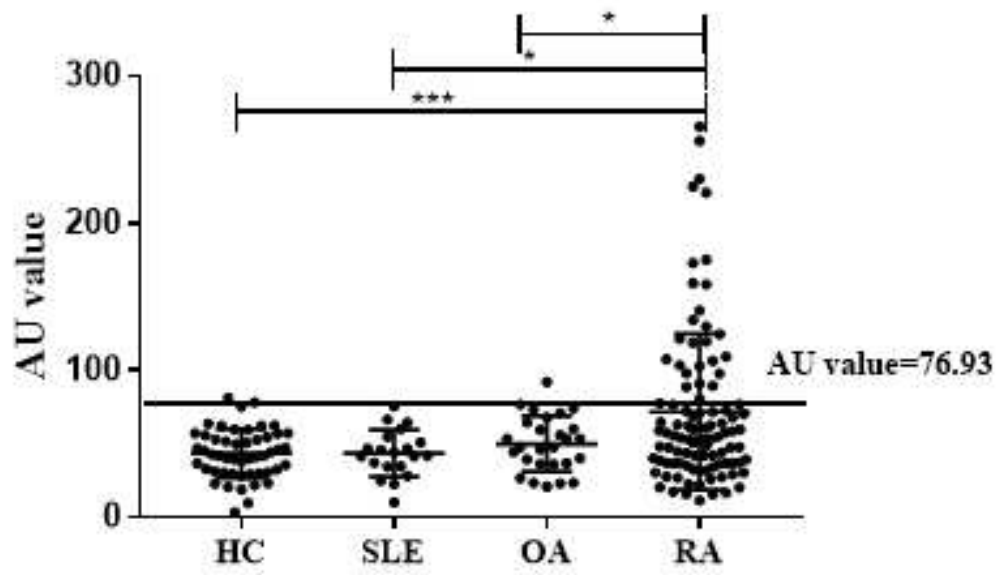

Figure 1

Comparison of serum levels of anti-cLBP antibodies between RA, OA, SLE patients and HC. ns, P>0.05; *

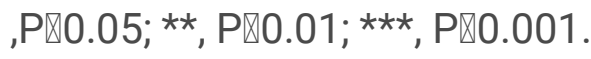




\section{Figure 2}
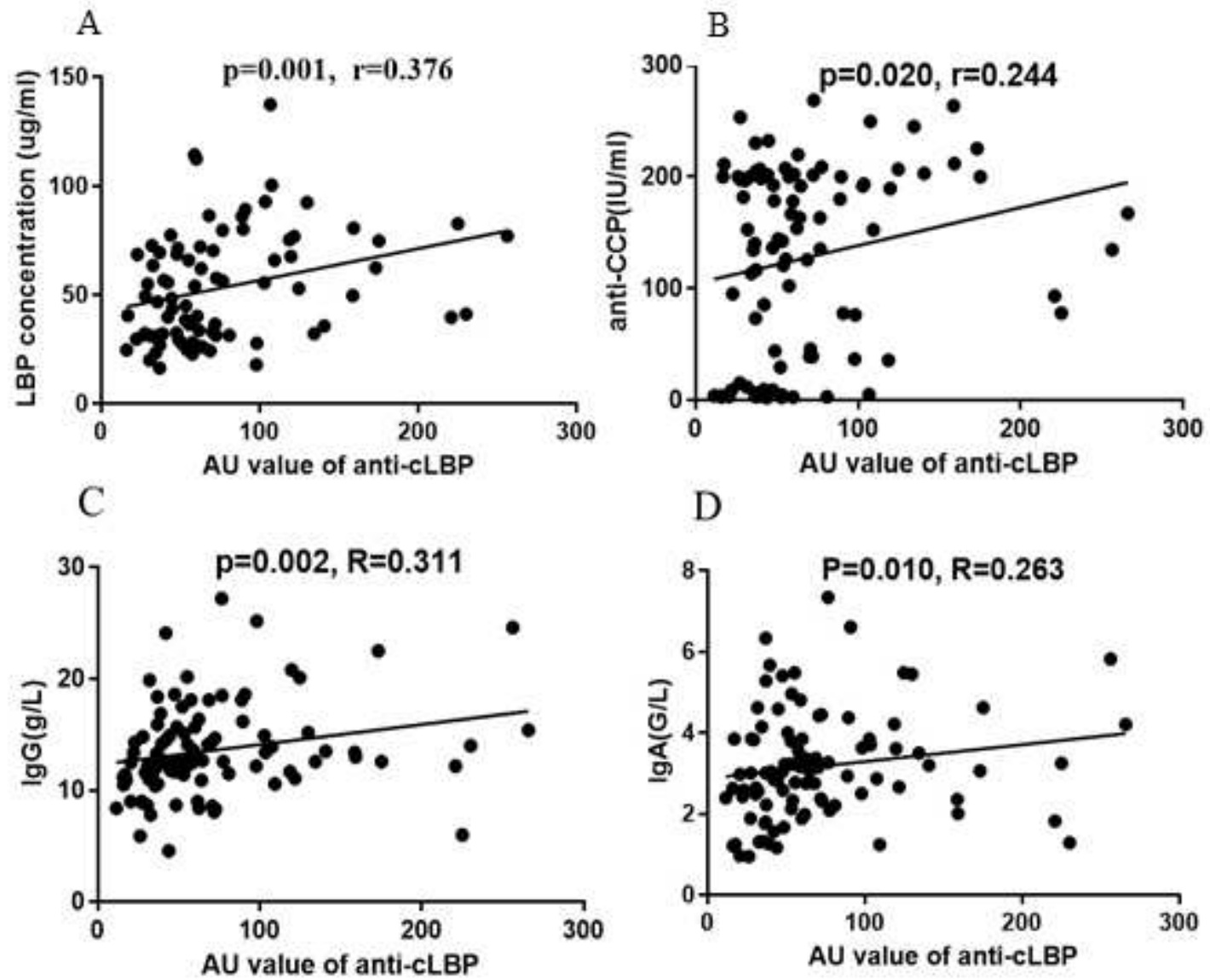

Figure 2

Correlation between anti-cLBP antibody and clinical parameters. A-D: Anti-cLBP antibodies positively correlated with LBP concentration, anti-CCP, IgG and IgA. $p<0.05$ were considered statistically significant. r: correlation coefficient. 